\title{
Laparoscopic cholecystectomy in children and adolescents
}

\author{
Serviço de Cirurgia do Aparelho Digestivo do Hospital Nove de Julho - São Paulo, Brazil
}

\begin{abstract}
During the period between August 1991 and November 1995, seven patients under age 17 were submitted to videolaparoscopic cholecystectomy (LC). Two were males and five females with ages ranging from 12 to 16 years (mean 13.8 years). The diagnosis of chronic cholecystitis with gallstones was made by the clinical history and physical and ultrasonographic examinations. There was no evidence of an association with hemolytic diseases, familial hyperlipidemia or Glucose-6-phosphate dehydrogenase (G6PD) deficiency. The surgery was performed under general anesthesia and the abdomen approached by four ports: a $10 \mathrm{~mm}$ umbilical incision, a $5 \mathrm{~mm}$ cystic, a $5 \mathrm{~mm}$ one at the xiphoid appendix and a $10 \mathrm{~mm}$ one at the left lateral margin of the left rectus abdominal muscle between the umbilical scar and the xiphoid appendix. Operative time averaged 120 minutes (105-150 min). One case required conversion to laparotomic approach because of Mirizzi's Syndrome, which was diagnosed by intraoperative cholangiography performed in all cases. There were no deaths or major postoperative complications. Hospital stays ranged from 1-3 days in the six patients submitted to LC. Thus LC in children can be considered a good method, requiring only more care regarding the use of proper equipment, complete and careful dissection of the biliary hilus, and intraoperative cholangiography. The latter is indispensable, as these children can present a higher rate of anatomic anomalies. The advantages of this technique include a less painful postoperative period with a faster recovery, and it is especially recommended in children, who are less tolerant to physical restriction and pain than adults.
\end{abstract}

UNITERMS: Videolaparoscopy, Cholecystectomy and Pediatric surgery.

\section{INTRODUCTION}

$\mathrm{C}$ hronic cholecystitis with gallstones is relatively common in adults but infrequent in children. First described by Gibson of Leith in 1721 , it can begin at any age but usually occurs between 40 and 50 years and is more frequent in females $(4: 1)$. When occurring in infancy, it is associated with complications of prematurity; in adolescence it commonly appears associated with hemolytic diseases.'

With the widespread use of ultrasonography, its diagnosis has become more frequent, and it is recognized more and more in younger age groups. Starting with the

\section{Address for correspondence:}

\section{Bruno Zilberstein}

Serviço de Cirurgia do Aparelho Digestivo do Hospital

Nove de Julho

Av. Brasil, 703 - Jd. América

São Paulo/SP - Brasil - CEP 01431-000 introduction of videoendoscopic surgery at the beginning of the nineties, with its inherent advantages, and allied with ultrasonography, cholecystectomy was also indicated in the younger age group.

Among services which perform Laparoscopic Cholecystectomies (LC), the prevalence in the younger age group varies and no statistical data is available. Different authors report random figures (Table 1). This study analyzes the results from 1991 to the present of LC in children, emphasizing the technical precaution in this procedure.

\section{MATERIAL AND METHODS}

\section{A) PATIENTS}

During the period from August 1991 to November 1995, 614 LCs were performed in our service. Among 


\begin{tabular}{|c|c|c|c|c|c|}
\hline \multicolumn{6}{|c|}{ Table 1} \\
\hline Author/year & $\begin{array}{l}\text { No. of } \\
\text { patients }\end{array}$ & Complications & Conversions & Deaths & $\begin{array}{l}\text { Hospital } \\
\text { Stay }\end{array}$ \\
\hline Vinorgrad $/ 93^{12}$ & 14 & 4 & 2 & 0 & $24 \mathrm{~h}-7$ days \\
\hline Pintus $/ 95^{13}$ & 1 & 0 & 0 & 0 & $48 \mathrm{~h}$ \\
\hline Newman/91 14 & 5 & 0 & 0 & 0 & $24 \mathrm{~h}$ \\
\hline Davidoff/92 15 & 12 & 0 & 0 & 0 & $48 \mathrm{~h}$ \\
\hline Cervantes $/ 92^{16}$ & 1 & 0 & 0 & 0 & $24 \mathrm{~h}$ \\
\hline Sigman $/ 91^{17}$ & 2 & 0 & 0 & 0 & $24 \mathrm{~h}$ \\
\hline Holcomb/94 & 27 & 1 & 0 & 0 & $24 h$ \\
\hline Moir/92 5 & 6 & 0 & 0 & 0 & $24-48 h$ \\
\hline Hatley/95 ${ }^{18}$ & 20 & 2 & 0 & 1 & $55 \mathrm{~h}$ \\
\hline Guerlud/ $/ 94^{4}$ & 1 & 0 & 0 & 0 & $24 \mathrm{~h}$ \\
\hline Total & 94 & 7 & 2 & 1 & - \\
\hline
\end{tabular}

Conversion Factors and Complications: Agnesia of the gallbladder, bleeding, presumed lesion of the bile duct, perforation of the gallbladder, choledocolithiasis and acute pancreatitis.

them, seven (1.14 percent) were on patients under 17 years of age. Two patients were males and five females, with ages ranging from 12 to 16 (mean 13.8 years). The diagnosis was based in all cases on the patient's clinical history physical and ultrasound examinations (Table 2).

The chief symptom in all cases was abdominal pain in the right hypochondrium, together with other clinical symptoms such as fever and vomiting (Table 2). The laboratory findings did not demonstrate an association with hemolytic diseases, familial hyperlipidemia or G6PDH deficiency in any of the children. In all cases, surgical indication was due to recurrent bouts of abdominal pain.

\section{B) TECHNIQUE:}

LC is performed under general anesthesia with the patient in a semigynecological position. The surgeon stands

\section{Table 2}

\begin{tabular}{|c|c|c|c|}
\hline No. & Age & Sex & Symptons \\
\hline 1 & 13 & M & $\begin{array}{l}\text { Rt. hypochondrial pain, vomiting, } \\
\text { nausea }\end{array}$ \\
\hline 2 & 12 & $M$ & Rt. hypochondrial pain, nausea \\
\hline 3 & 16 & $\mathrm{~F}$ & Rt. hypochondrial pain, Murphy + \\
\hline 4 & 15 & $\mathrm{~F}$ & Rt. hypochondrial pain, vomiting \\
\hline 5 & 15 & $\mathrm{~F}$ & Rt. hypochondrial pain, fever \\
\hline 6 & 12 & $\mathrm{~F}$ & Rt. hypochondrial pain, vomiting \\
\hline 7 & 14 & $\mathrm{~F}$ & Rt. hypochondrial pain, vomiting \\
\hline
\end{tabular}

between the patient's legs, the first assistant and scrub nurse are to the surgeon's right, and the second assistant to the left.

The Veress needle is inserted through a $1 \mathrm{~cm}$ incision at the level of the umbilical scar and pneumoperitoneum is obtained, (intra-abdominal pressure $12 \mathrm{mmHg}$ ) followed by introduction of the first $10 \mathrm{~mm}$ trocar for insertion of the camera. The other trocars are introduced under direct vision and are located at:

a) a $5 \mathrm{~mm}$ trocar at the level of the right upper quadrant for insertion of the grasping instruments and exposure of the field.

b) a $10 \mathrm{~mm}$ trocar at the level of the left lateral margin of the left rectus abdominal muscle, at the midpoint between the umbilicus and the xiphoid appendix. The instruments of the surgeon's right hand are introduced through these ports, as well as the dissecting forceps, hook, scissors, electrocautery and the clip applier.

c) a $5 \mathrm{~mm}$ trocar, at the level of the xiphoid appendix for insertion of a "liver retractor," employing for that the suction/irrigator.

Dissection begins by opening Calot's triangle for visualization of the cystic duct and cystic artery. Routinely, the author begins by dissecting the peritoneum from the biliary pedicle through the posterior surface to avoid injury to vital structures. Initial ligation of the cystic artery is recommended to avoid its rupture during manipulation of the biliary hilus. The next step is the proximal ligation of the cystic duct as closely as possible to the infundibulum of the gallbladder, and the introduction of the cholangiography catheter. This was possible in all cases. 


\section{Table 3}

\begin{tabular}{lllll}
\hline No. & Intraoperative findings & Duration & $\begin{array}{l}\text { Postoperative } \\
\text { Symptons }\end{array}$ & $\begin{array}{l}\text { Hospi. } \\
\text { Discharge }\end{array}$ \\
\hline 1 & Chronic gallstone disease + cholesterosis & $140 \mathrm{~min}$ & none & 1 st p.o. day \\
2 & Chronic gallstone disease + cholesterosis & $150 \mathrm{~min}$ & headache & 2 nd p.o. day \\
3 & Chronic gallstone disease & $105 \mathrm{~min}$ & none & 1 st p.o. day \\
4 & Chronic gallstone disease + cholesterosis & $120 \mathrm{~min}$ & none & 1 st p.o. day \\
5 & Chronic gallstone disease + lymphoid & $150 \mathrm{~min}$ & vomiting & 3 rd p.o. day \\
& hyperplasia in perivesicular lymph node & & & \\
6 & Chronic gallstone disease & $120 \mathrm{~min}$ & none & 1 st p.o. day \\
7 & Chronic gallstone disease + Mirizzi's Syndrome & $300 \mathrm{~min}$ & incisional pain & 1 st p.o. day \\
\hline
\end{tabular}

Concluding the cholangiography, the cystic duct is ligated distally with two clips, proximally to the orifice of the catheter's entry.

Using electrocautery, the gallbladder is dissected from the hepatic bed and the liver retracted to provide adequate exposure of the dissection site. A plastic bag is used to remove the gallbladder and is extracted through the umbilical port. The camera is placed in the left $10 \mathrm{~mm}$ port to facilitate this maneuver. The hepatic bed is then inspected.

\section{RESULTS}

Intraoperative findings: no acute cholecystitis was observed. Cholesterolosis was observed in three cases and in one, lymphoid hyperplasia in a perivesicular lymph node.

Cholangiography was normal in six patients. Various intrahepatic stones (Mirizzi's Syndrome) ${ }^{2.3}$ were observed in the seventh case. Conversion to open surgery was resorted to in this case, and choledocolithotomy and a biliodigestive Roux en Y anastomosis performed.

No bleeding, intraoperative complications, or deaths occurred in any of the cases. The average duration of the surgery was 120 minutes ( $105-150 \mathrm{~min}$ ) from initiation of anesthesia to closure of the incisions. One patient complained of headache in the immediate postoperative period (p.o.), which improved with common analgesics; two episodes of vomiting occurred in another patient during the first 24 hours, and the patient submitted to laparotomy presented pain in the abdominal incision, improved with analgesics (Table 3 ). No other more severe complications were noted.
The six patients who underwent laparoscopic cholecystectomy were fed between 8-24 hours p.o. (average 12 hours). They were discharged on the average 1.5 days p.o. (1-3 days) and returned to their normal activities 2-3 days later.

\section{DISCUSSION}

Chronic cholecystitis with gallstones is a wellknown clinical entity which is more prevalent in females. It is uncommon in children and adolescents' (Table 2). The patients in this age group normally present a broad anatomic variation of the biliary hilus, generally diagnosed by intraoperative cholangiography or by preoperative retrograde endoscopic cholangiography. ${ }^{4.5}$ None of the patients in this series underwent this exam preoperatively, having been submitted only to intraoperative cholangiography, which is mandatory in biliary surgery, especially in children..$^{6-8}$ The fact that injury to the main bile duct is the most frequent complication reported in the literature ${ }^{9-11}$ confirms this. This is significant due to the gravity of the complication, for a benign disorder is being treated which normally has a good surgical outcome..$^{2.3}$

In spite of the small sample group, out of the seven patients, Mirizzi's Syndrome was diagnosed in one (14.3 percent), thus confirming the high incidence of anatomic anomalies. It is worth emphasizing that once this syndrome was diagnosed, it was opted to convert to open surgery because the laparoscopic method was not completely safe ${ }^{6.8}$ Consequently, the commitment is to the complete management of the disease, and not to the therapeutic method. 
Laparoscopy has been enthusiastically received for the realization of cholecystectomies because it has made the operation less aggressive and the p.o. period easier. Nevertheless, this method should be carefully applied in children because they are physically smaller than adults. Furthermore, anatomic alterations of the biliary hilus are more common in young patients with chronic gallbladder disease. Normally, the same instruments are used as in adults and they are not always suitable, since the space is smaller and the abdomen has less depth. Further more, children's livers are relatively larger. ${ }^{5}$ Therefore, the placement of the trocars in the abdomen does not obey the rules of positioning, the distance between the trocars may be changed, and sometimes to obtain better exposure of the biliary hilus, a fifth trocar may be inserted. The latter is introduced into the right flank, slightly below the one placed in the right upper quadrant. This port serves to grasp the fundus of the gallbladder and provides traction in the cranial direction to expose the biliary hilus. Three of our cases required the use of a fifth trocar.
Operative time was relatively longer than that mentioned in the literature (Table 3). This occurred because we attempted to dissect and separate the anatomic structures more carefully to avoid injury to the biliary hilus. The outcome, however, was similar to LC in adults, as the surgery is less traumatic.

Based on the analysis of this material, surgery should be accomplished with the utmost care, since anatomic anomalies may be present and cholangiography is imperative to assess the situation of the main bile duct.

As we could observe, laparoscopic cholecystectomy in children is a good procedure, merely requiring more judicious care in the use of proper equipment and complete and careful dissection, without omitting the classical steps of the operative technique and intraoperative findings. Its advantages, such as a less painful postoperative, a speedier recovery, and a quicker return to normal activities recommend it, particularly in children who are more intolerant to physical restriction and pain than adults. Even so, it should never be placed above the commitment to the complete treatment of the disease and the total safety of the intervention.

\section{RESUMO}

Durante o periodo de agosto de 1991 a novembro de 1995, foram submetidos a colecistectomias por videolaparoscopia 7 pacientes com idade inferior a 17 anos, sendo dois do sexo masculino e cinco do feminino, A idade variou de 12 a 16 anos (média de 13,8 a). O diagnóstico de colecistopatia crônica calculosa foi feito pela história clínica, exame físico e estudo ultrasonográfico. Em nenhum caso foi evidenciada a associação com doenças hemoliticas, hiperlipidemia familial ou deficiência de Glicose-6-fosfato desidrogenase. A anestesia era sempre geral e o abdome era abordado por 4 portais: umbilical (10 mm), ponto cístico $(5 \mathrm{~mm})$, apêndice xifóide $(5 \mathrm{~mm})$ e borda lateral esquerda do músculo reto abdominal esquerdo entre a cicatriz umbilical e 0 apêndice xifóide $(10 \mathrm{~mm})$. O tempo médio do procedimento foi de duas horas $(1: 45-2: 30)$, e em um caso optouse pela conversão da cirurgia por se tratar de Síndrome de Mirizzi, a qual foi diagnosticada pela colangiografia intra-operatória, procedimento este realizado em todos os casos. Năo ocorreram óbitos nem complicaçōes no pós-operatório. O tempo de internação variou de 1 a 3 dias nos 6 pacientes submetidos à colecistectomia laparoscópica. Dessa forma, a colecistectomia laparoscópica em crianças pode ser considerada um bom método, requerendo apenas mais cuidados quanto ao emprego de instrumental adequado, dissecção completa e cuidadosa do hilo biliar e realização de colangiografia intra-operatória, que é indispensável, pois essas crianças podem apresentar maior incidência de anomalias anatômicas. Suas vantagens como pósoperatório menos doloroso e recuperação mais rápida recomendam-na principalmente na criança que tolera menos que o adulto a restriçăo física e a dor. 


\section{REFERENCES}

I. Friessen CA, Roberts CC. Cholelithiasis: Initial characteristics in children, case analysis and literature review. Clin Pedriat 1989;28:294.

2. Moser JJ, Baer HU, Blumgart LH, et al. Le syndrome de Mirizzi - une contre-indication à la chirurgie laparoscopique. Helv chir Acta 1992;59:577-80.

3. Posta CG. Unexpected Mirizzi Anatomy: A major hazard to the common bile duct during laparoscopic cholecistectomy. Surg Laparos Endos 1995;5 (5):412-14.

4. Guerlud M, Rincones VZ, Jaen D, et al. Endoscopic sphincterotomy and laparoscopic cholecystectomy in a jaundiced infant. Gastro Endos 1994;40:99-102.

5. Moir R, Donohue JH, van Heerden JA. Laparoscopy cholecystectomy in children: Initial experience and recommendations. J Ped Surg 1992;27(8):1066-70.

6. Holcomb III GW, Sharp KW, Olsen DO. Laparoscopy cholecystectomy in the pediatric patient. J Ped Surg 1991;26(10):1186-90.

7. Holcomb III GW. Laparoscopy Cholecystectomy. Ped Ann 1993;22:657-62.

8. Holcomb III GW, Naffis D. Laparoscopy cholecystectomy in infants. J Ped Surg 1994;29(1):86-7.

9. Hunter, JG. Avoidance of bile duct injury during laparoscopic colecystectomy. Am J Surg 1991;126:71-6.
10. Meyers WC, Branum GD, Farouk M, et al. A prospective analysis of 1,518 laparoscopic colecystectomies. N Engl J Med 1991;324:1075-8.

11. Peters JH, Ellison EC, Innes JT, et al. Safety and efficacy of laparoscopic colecystectomy: A prospective analysis of 100 initial patients. Ann Surg 1991;213:3-12.

12. Vinograd I, Halevy A, Klin B, et al. Laparoscopy Cholecystectomy: Treatment of choice for cholelithiasis in children. World J Surg 1993;17:263-6.

13. Pintus C, Coppola R, Talamo M, et al. Laparoscopy cholecystectomy in a 23-month-old infant. Surg Laparos Endos 1995;5(2): 148-50.

14. Newman KD, Marmon LM, Attorri R, et al. Laparoscopy cholecystectomy in the pediatric patients. J Ped Surg 1991;26(10):1184-5.

15. Davidoff AM, Branum GD, Murray EA, et al. The technique of Laparoscopy Cholecystectomy in children. Ann Surg 1992;215(2):186-91.

16. Cervantes J, Rojas G, González A.G, et al. Colecistectomía laparoscópica en pediatría. Informe del primer caso en la literatura nacional. Bol Med Hosp Infant Mex 1992;49(6):380-3.

17. Sigman HH, Laberge JM, Croitoru D, et al. Laparoscopy Cholecystectomy: A treatment option for gallbladder disease in children. J Ped Surg 1991;26(10):1181-3.

18. Hatley RM, Crist D, Howell CG, et al. Laparoscopy Cholecystectomy in children with sickle cell disease. Am Surg 1995;61:169-71. 